\title{
Maori and mainstream: Towards bicultural reporting
}

The NZ news industry - owners, management and education sectors has long agreed that the news media requires more Maori journalists. The industry has long recognised an imbalance does exist, whatever its characterisation. But the solution is not as simple as it seems.

\section{By IAN STUART}

THIS article follows "Maori and Tauiwi Media", by examining issues of Maori journalism training in a society with a growing Maori population and Maori news media. It takes the position that communication methods and systems are based within cultures, looks at issues of the role of the news media in each culture, then at news selection processes, angles and writing styles. It argues that journalism teaching practices need to change to take into account these differences when training Maori to be journalists.

The news industry — owners, management, and education sectors — has long agreed that the news media requires more Maori journalists. The call for more Maori journalists has largely been a response to the pressure from Maori for better reporting of Maori news. The industry has long recognised an imbalance does exist, though there are problems over the characterisation of that imbalance. But whatever the imbalance is, industry has at least recognised that increasing the numbers of Maori reporters is one answer to the problem. However, the answer is nowhere near as simple as it appears. It appears Maori are not attracted to mainstream journalism schools. This article attempts to address some issues and discusses some of the changes necessary for New Zealand's news reporting to become truly bicultural.

42 PACIFIC JOURNALISM REVIEW 82002 
The approach taken in this article is to look at how journalists describe their role, (rather than external academics' summation of a journalist's role) and place this within its social context - as a Pakeha communications system. It then shifts to Maori contexts and examines what happens when western journalism is practised in a different social system, and identifies issues which need to be tackled to produce truly bicultural reporting in New Zealand.

This article attempts to identify some of the key differences in news approaches between the mainstream and the Maori media. It then argues that a different teaching approach is needed in journalism schools to allow these differences to emerge and develop.

Obviously, the news production across the country will need to change if graduates with different skills are allowed to put new and different skills into practice in the workplace. The journalism training schools, as academic leaders, should be the ideal place to begin this debate, though I am not naive enough to think that the schools are totally free of the employers' influence, most notably exercised through the New Zealand Journalism Training Organisation (NZJTO), which controls what is taught within its approved qualifications.

\section{Whose news?}

There are now two different news media in New Zealand - an established mainstream media and a growing Maori media. Each works in different ways, as I will discuss shortly. These demand different approaches to identifying and writing news. So the fundamental question is: Which media are Maori training to be journalists for? To work in the mainstream media or the growing Maori media? And within the mainstream media, are Maori required to report Maori issues for Pakeha or for Maori? Each requires different approaches.

\section{Biculturalism}

It is important to understand that there are two cultures in New Zealand Maori and Pakeha, indigenous and settler. This is a political statement, rather than a descriptive statement. The equivalent descriptive statement is: New Zealand is a multicultural country. However, the implications of biculturalism are political and about power sharing, rather than the descriptive or social/ anthropological statement of New Zealand's multiculturalness. It is important to keep the political nature of biculturalism in mind. And also to realise that Maori power structures and relationships are different from the equivalent 


\section{Maori culture}

remains distinct and

separate within NZ.

Biculturalism is

about allowing those

two power structures

to function side by

side. The media, as

an active element of

the power

processes, has to

take biculturalism

into account.
Pakeha processes. Despite many years of a dominant settler culture, Maori culture remains distinct and separate within New Zealand. Biculturalism is about allowing those two power structures to function side by side. The media, as an active element of the power processes, in whatever way, has to take biculturalism into account.

It is also important to recognise that the news media, as we know it in New Zealand, has developed as an integral part of western democratic culture. In fact, as Habermas argues in his seminal work The Structural Transformation of the Public Sphere, the news media had a major impact on the development of western democratic culture. But this means that news media styles are grounded in western culture - western democracy, western decision-making processes and western narrative styles - western perceptions and definitions of "news". These are different from Maori approaches to decision-making, narrative styles and "news". They are so different that Maori approaches are nearly impossible to reconcile with western cultural approaches to "news".

\section{Democracy and decision making}

The free, western, news media — the Fourth Estate — has long been regarded as an important part of western democracy. Journalists talk about their role as providing the information people need to function in a democracy.

An illustration of this was supplied recently by Hawke's Bay Today's advertising of itself. ${ }^{2}$ (See opposite page.)

But both of these advertising graphics assume that the knowledge being shared by the community is what the community as a whole wants to read. However there is no such things as pure knowledge, especially when it comes to interpretations of events and "news". "Knowledge" contained in news is usually written from a Pakeha perspective, presented in Pakeha styles and in a 44 PACIFIC JOURNALISM REVIEW 82002 

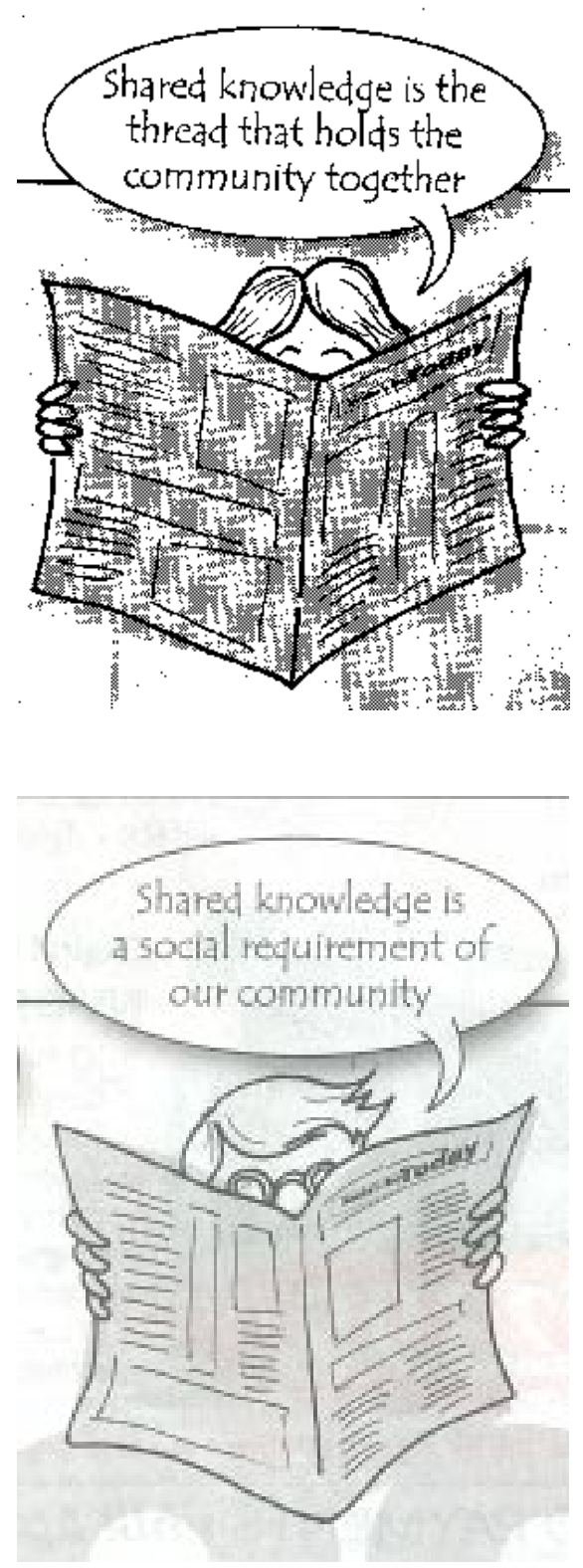

\section{Maori women turning to crime - report}

\section{CHFASTINE LANGDON}

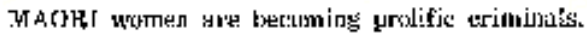

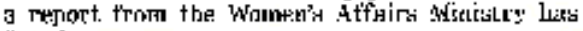
ionud.

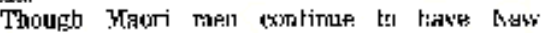
Zealandy lighest race of offendill: Maori incol aro boomlus increasingly draph to srime.

They ane llive times rnore likely to be profec-

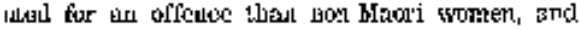

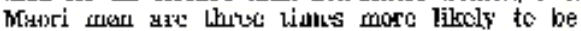

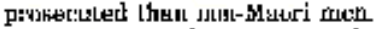

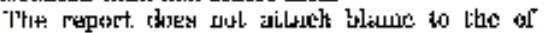

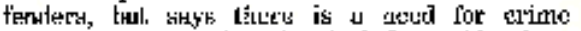

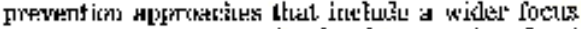

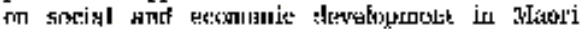

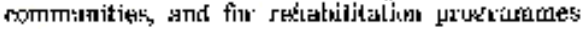

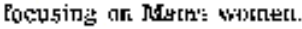

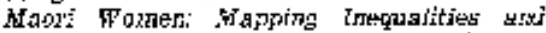
Poluture Wars Forw ard, issued veseerdsy by tho-

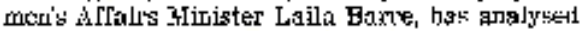
the sitalus of hloold spomea and piris relatise to

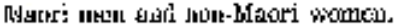

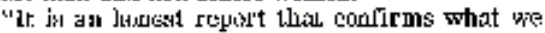

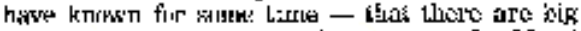

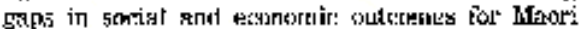

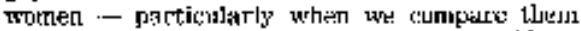
to their Pakcha comererparts:" Mis Harue said.

Atsuls i2 por cent of the population in Netr zealand is 3forai. But in the area of offendtirs, Basci musks up 51.4 par bent of all wonen

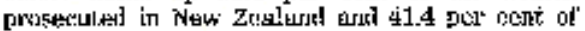

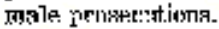

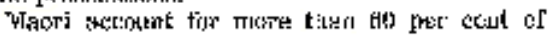
all imprisoned somen atid 511 par sent of ispuris-

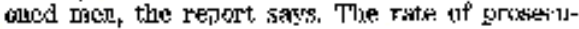

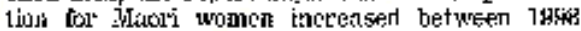
and lofy, wivile the rate for mon fell.

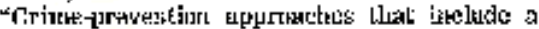

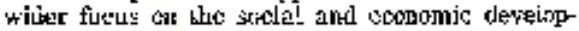
ment of Bisuri sidvuld $\mathrm{k}$. considered," the report 4:47уя.

It repomminds rehalijiliatiut proxretemes

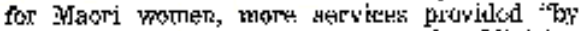

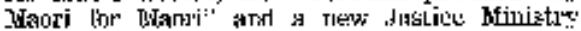
erime-euttings stratesy-

Hawke's Bay Today advertisements; The Dominion crime report. 


\section{INDEX}

Pakeha format. Maori experiences of the community they live in are different from Pakeha experiences of the same community. And thus, the knowledge about the community and the knowledge they share with others about the community is different.

A classic example comes from The Dominion in September 2001, which ran a story under the headline:

\section{Maori women turning to crime - report ${ }^{3}$}

This story (see previous page) constructs Maori as a "them", while the rest of "us" - the community - are led to believe things about Maori women which are not supported by the report. As well, Maori receiving the "information" contained in such stories will experience it differently to Pakeha. To Maori this is a story about "us" - about "our women", but to Pakeha it is about a "them". In fact, it constructs Maori women as a trouble-making "them". Maori will certainly not experience it as shared information that holds the community together, more likely as shared information that separates them from the community.

This is the type of story which the mainstream media needs to learn to report in a different way if it is to serve the interests of Maori as well as Pakeha.

\section{Community watchdogs}

Journalists describe their jobs as "watchdog" for the citizens ${ }^{4}$ - attending public meetings when the public cannot, asking questions of elected politicians and public bodies, when the citizens can not, and reporting back to the voters. As Jim Tucker writes: “The journalist is society's reporter, observer, commentator, an alarm bell to expose what is amiss." 5

This function of the news media allows public scrutiny of decisions - from Parliament, to regional and city councils, to courts (justice must be seen to be done), to the new health boards. In all forms it is a necessary part of our democracy.

This process not only allows people who are not at such meetings or events to see what decisions were reached, but to critique and comment on those decisions, in fact to participate in the decision-making process. There have been several instances of decisions made in the public arena, or decisions overturned in the media, rather than in council chambers or Parliament. Auckland's 
Britomart Centre is one such decision widely canvassed in the public arena, made several times and revised because of community pressure and public debate allowed, even instigated, by the news media. This is how our democracy functions.

Maori processes are different. Decisions are made at hui, on marae, in community centres, by the people at the meeting. Discussions are free-flowing and decisions are made by the participants. Once the decision has been made it is announced to other people affected by that decision, if they were not at the meeting. But the discussion stays within the meeting and the group publicly supports that decision. There is no wider public discussion of that decision. The important point here is that people at the meeting make the decision — and only those people.

Introducing western news reporting models into Maori society changes the process. Firstly it makes the discussion, once behind closed doors, public property. But more importantly it opens the decision to public scrutiny and critique. It allows people not at the hui to comment and participate in the decision-making process.

This represents a fundamental change to Maori decision-making process, but also a fundamental challenge to the rights of hapu and iwi to make their own decisions. Maori decisions are not only opened to question and critique by other Maori but by Pakeha as well.

It may be totally inappropriate for other Maori to comment on decisions made by hapu and iwi. In fact New Zealand history and Maori radicalism is full of examples of groups fighting to maintain their independence - their tino rangatiratanga. And if these groups fight to maintain their autonomy within Maori society, how much stronger they fight to maintain autonomy in the face of the Pakeha, the white colonizer, the settler Government.

While Maori commonly accuse the mainstream media of misreporting, or inaccurately reporting, Maori events and issues, it is possibly more likely this is an expression of the fact that the reporting the process is culturally inappropriate. One station manager, when asked about reporting the arguments and discussion within the Maori world, replied: "We do not air our dirty linen in public". While expressed as a negative cliché from the western world, this statement is a reflection of Maori awareness of the impact of reporting on Maori processes. It is an inherent awareness that news reporting changes the nature of Maori decision-making processes and therefore will have a significant impact on Maori culture and processes. 


\section{INDEX}

\section{Newsmakers}

Not reporting Maori decision-making processes, but only the results of the process must mean that Maori newsmakers should be created and presented in different ways. Many of the Pakeha-selected newsmakers become newsmakers because they are in positions where their opinions can be put into practice, and affect a larger number of people. They express their opinions in the media as part of the public decision-making processes. One example is politicians, often holding portfolios as ministers, or who have areas of responsibility as opposition members. They can also be opinion leaders because the media gives them airtime, i.e. they are creations of the media itself.

But however they got to be opinion leaders, they have influence within the public arena. It is important to recognise that such people expressing their opinions publicly, and publicly contradicting each other, let the voters hear differing opinions and make decisions about which groups, parties or people to support and which to oppose. This is an important part of Pakeha decisionmaking processes.

It is also important to recognise that the news media allows political leaders to gain external validation for their views and actions. This validation can come in a variety of forms. The media are involved in the attempted validation process through its use of political commentary and discussion in the newspapers, radio and television news programmes. The news media uses two forms of validation: the first takes the form of a question, asking is the decision one which is good for the country, the city, the voters and taxpayers, or for business and the community. This form of validation is commonly done by interviewing "experts". The second one takes the form of validation by asking if a majority of voters will accept the decision and re-elect the party to the Government benches. This is done with opinion polls. Validation can also occur through letters to the editor, and talk-back radio, where people — "voters", "tax-payers" or "ratepayers" - have their say publicly.

If, however, Maori decisions are not to be made in public in the same way as Pakeha decisions, the news media will have to change the way it thinks of Maori opinion leaders and the way it presents them in public. The news media's role in allowing time and space for Maori opinion leaders and reporting Maori opinions must fit with Maori culture and not simply impose western processes on Maori.

And, in fact, the people selected by reporters as Maori opinion leaders, or 
as Maori voices, may be the wrong people in Maori terms, simply because they are reported by the news media. The people Maori look to as opinion leaders are the people who listen to the arguments in hui, then make decisions for the people in that setting, without seeking external justifications or external validations of their decisions. Such validations are found on the marae atea, the place of argument and conflict, or in the fact that people carry out their decisions - they vote with their feet. The challenges to tribal authority come on the marae and in the community - not in the newspapers, radio bulletins or television news. And therefore the validation comes from the community, first hand from the marae itself. But decision-makers are accepted as such because, fundamentally, they are seen as having made good decisions in the past.

\section{News as history}

News has also been described as "instant history". But here too there are major problems between Maori and Pakeha reporting. Maori views of history are different from others. Maori interpretations of a historical narrative, of the meaning of events within that history, differ from Pakeha interpretations, as does the selection of important events, and the relative importance of events. Here it would be useful to bring in an academic model of the narrative to look at differing views of "instant history".

\section{Narrative theory}

One way of explaining, in news terms, the different approaches to instant history is through Todorov five stages of a narrative ${ }^{6}$. Todorov says every narrative begins with a status quo. Stage two is a disruption to that status quo, followed by stage three, a deterioration of conditions. Stage four is a working through the issues to a resolution and stage five is the restoration of the status quo, or the establishment of a new status quo.

As Fiske uses this model, by definition, all news is a disruption to the status quo. The status quo is not reported. This is normal life, nothing unusual occurs. However, take a fatal car accident — always news. It is a disruption for the people directly involved. By reflection it is also a disruption for the community. Todorov's stages two and three happen almost instantaneously. There may be issues to work through, such as charges against one or both driver. Then a status quo is resumed. People have been punished, if necessary. The police and road safety authorities have made noises in the community about 


\section{INDEX}

driving, seats belts and general road safety, then there is a return to the status quo.

This is only one news story. But a different narrative involves road safety in general. In this narrative, one story of a car crash is one episode in a continuing community discussion around road safety and related issues. In this narrative we are still at the stage of working through the issues, having experienced a deterioration in road safety, which lead to a high road toll. The road toll has since been reduced and people are becoming aware of the issues. It is doubtful we will establish a new status quo, unless the community can decide on what is an acceptable level of road deaths.

This narrative involves the whole community as both Maori and Pakeha die on the roads. However applying the model to a different narrative, one that involves Maori and Pakeha, shows the differences in the narrative. The table (opposite) uses the Pakaitore/Moutoa Gardens protest and place its various stages within Todorov's theory, using Pakeha and Maori narratives.

It is clear in this one example that Pakeha perspectives of events can be at variance with Maori perspectives. And there are plenty of other examples.

This means the instant history Maori write will be different from their Pakeha counterparts. The stages in the narrative will be different, the "angle" chosen, the emphasis given to facts and events. In fact, the whole way the story is presented will be different.

It is important to note here that the agent causing the disruption is usually written into a story as the active party - and frequently presented in a negative way. They are the ones, after all, who cause the "disruption". However ideas of who is causing the disruption can differ, especially between Maori and Pakeha perspectives. The means approaches to a story will vary widely between the two cultures.

\section{Writing for audiences}

Journalists have recognised the need to write for an audience - it is a skill that is taught in all journalism schools. It is obvious then that Maori journalists potentially have three audiences - A Pakeha audience in the mainstream media, a Maori audience who use the mainstream media and a Maori audience using the Maori media. In fact, all reporters have a number of different audiences, but this is not the place, nor the space, to expand on that idea. That does not, however, negate this approach, as the audiences journalists write for fall within one overall cultural group. Maori fall outside the common cultural group the news is aimed at - the settler culture.

50 PACIFIC JOURNALISM REVIEW 82002 
BICULTURALISM

\begin{tabular}{|c|c|c|}
\hline & PAKEHANARRATIVE & MAORI NARRATIVE \\
\hline 1. Status Quo & $\begin{array}{l}\text { Council controls } \\
\text { Gardens }\end{array}$ & $\begin{array}{l}\text { Maori control } \\
\text { Pakaitore }\end{array}$ \\
\hline 2. Disruption & $\begin{array}{l}\text { Maori protestors } \\
\text { move on }\end{array}$ & $\begin{array}{l}\text { Council takes it over } \\
\text { as a gardens - } \\
\text { rename it Moutoa } \\
\text { Gardens }\end{array}$ \\
\hline 3. Deterioration & $\begin{array}{l}\text { Protest continues } \\
\text { confrontations with } \\
\text { the police/city council }\end{array}$ & $\begin{array}{l}\text { Maori excluded from } \\
\text { management of } \\
\text { ancestral lands }\end{array}$ \\
\hline $\begin{array}{l}\text { 4. Work through the } \\
\text { issues }\end{array}$ & $\begin{array}{l}\text { Court case/police } \\
\text { intervention/ } \\
\text { discussion }\end{array}$ & $\begin{array}{l}\text { Protest - } \\
\text { discussions with } \\
\text { settler Government } \\
\text { and Pakeha city } \\
\text { authorities }\end{array}$ \\
\hline $\begin{array}{l}\text { 5. Restoration of } \\
\text { status quo/new } \\
\text { status quo }\end{array}$ & $\begin{array}{l}\text { Maori leave } \\
\text { Gardens }\end{array}$ & $\begin{array}{l}\text { Council/Maori } \\
\text { become partners in } \\
\text { the management of } \\
\text { the Gardens }\end{array}$ \\
\hline
\end{tabular}

Todorov theory: using Pakeha and Maori narratives.

The news production skills required to service a Pakeha audience are different to the skills needed by a journalist servicing the needs of a Maori audience. This means a Maori journalist needs to be able to reach both audiences. However, Pakeha news controllers expect a Maori journalist to write in Pakeha news styles, while Maori audiences expect Maori journalists to write for them - to serve their needs, not the needs of the Pakeha news controllers and news systems.

A Maori journalist is not naturally a member of the Pakeha audience. They PACIFIC JOURNALISM REVIEW 8200251 


\section{INDEX}

therefore do not have inherent skills to call on to communicate to this audience. The reverse is equally true, Pakeha do not have the inherent knowledge of the Maori audience that allows them to easily communicate with their cultural groups.

This is why the news media believes it needs more Maori journalists. However, the media tends to use Maori reporters to write both for Maori audiences and for Pakeha audiences. This means a Maori journalist has to learn to communicate with two cultures - two audiences. Essentially then, a Maori journalist has to learn two approaches.

For educators, this means Maori journalism students have to be taught the communications system of a different culture - the communication system used by the news media. In effect, this is cross-cultural education. But this should be occurring in both directions. If Maori are expected to become bicultural reporters, then their Pakeha counterparts can become bicultural and the same expectations of cross-cultural learning and communication should be applied to them as well.

\section{Maori media}

At this point it would be useful to touch briefly on the Maori media itself. The Maori media works in a very different way to the Pakeha media, and this needs to be taken into account when Maori are trained to work in the Maori media. ${ }^{7}$ The Maori media is like many indigenous media throughout the world, it is a developmental media. Robie offers a model of the developmental media ${ }^{8}$ against which it is easy to see the elements of the Maori news media ${ }^{9}$. These illustrate the totally different approaches to news taken by mainstream and Maori media.

In terms of the skills used, the Maori media covers a wide range. There used to be iwi-based newspapers produced by people with no formal media training. In fact, these papers, often radically pro-Maori, or Ultra-Maori, frowned upon writers who had what was perceived as "Pakeha" media training. Often this was seen as a colonising process and therefore not desirable.

However, most of these iwi-based papers have ceased to exist. The major Maori news is through Maori radio, primarily from Mana Maori Media. Television news comes through Marae, Wakahuia and Te Karere and will also be available through the new Maori channel. These outlets all employ trained and experienced journalists and use mainstream news techniques, often adapted for the circumstances, but mainstream techniques nonetheless. One of those 52 PACIFIC JOURNALISM REVIEW 82002 
adaptations is in the concept of objectivity.

\section{Objectivity}

In a development media, conceptions of objectivity also differ. Fundamentally the development media could be said to be presenting "good news" not bad. This is true of the Maori media, which was set up to counterbalance the perceived negativeness of news about Maori in the mainstream news outlets. However, this open admission of differing perspectives in news selection results in the admission that Maori news is often not "objective" in the Pakeha sense.

In the first class that I had one day I announced the subject of the day's lecture would be "objectivity". Fifteen Maori students laughed out loud and said there was no such thing. I had to quickly rethink what I was going to say to them. The topic of the lecture was to have been objectivity — that it is a myth - and then to discuss journalist ideas of objectivity. However, the students, long on the receiving end of so-called Pakeha journalists' objectivity, inherently knew what I had wanted to teach them.

The point is that all stories are told from a particular perspective. Usually they are constructed from a Pakeha perspective. I recently heard a journalist say that objectivity did not mean assuming an objective perspective, which, he acknowledged, was impossible, but ensuring that articles presented both sides of a story, that facts were collected and presented in a fair way, and that both sides of issues were canvassed and presented fairly.

However, this kind of objectivity is still not true objectivity. What are "the facts" to collect is a subjective judgement. Which facts to highlight in intros, to present in order of importance in the inverted pyramid is a subjective judgement. What to highlight in the headline is also a subjective judgement.

\section{Maori writing styles}

Maori writing styles are also different from Pakeha often because Maori writers accept that objectivity is impossible and do not try for it. This means that many of the Maori media news stories are written discursively. There is no pretence at objectivity and no use of the inverted pyramid formula. In the mainstream news media this kind of discursive style is reserved for opinion pieces and leaders, written by experienced journalists and news executives. Sometimes junior reporters get to write columns, but columns too are usually reserved for more experienced reporters or by outside "experts" and commentators. Discur- 


\section{I had a former} student working for a Maori newspaper who was told that a story was 'too Pakeha'. However, the same story presented to a mainstream outlet would also have not been used, because it didn't fit formats
for presenting news. sive writing has no place in mainstream news reporting.

Maori writing styles can also be written in narrative styles. This is a culturally appropriate way of presenting information and has been used for hundreds of years by Polynesian cultures.

In a concrete example of differing writing styles and expectations of news executives, I had a former student working for a Maori newspaper who was told that a story was "too Pakeha". However, the same story presented to a mainstream outlet would not have been used either, because it did not fit the pre-conceived formats for presenting news.

\section{Effect on news}

All this means that Maori ideas of what makes news will be radically different from Pakeha ideas. Maori will choose different newsmakers, different angles and give events different emphasis and interpretations. The stories Maori reporters will want to write will be very different from the stories Pakeha reporters will write about the same events. Their selection of what makes news, in terms of a view of changes in history, in terms of what is the disruption, its causes and effects, in terms of the approaches (angles), intros and writing styles could all be very different from Pakeha reporters. But they are still legitimate selections.

\section{Journalist training and colonisation}

Maori reporters also acknowledge a responsibility to their community. This is inherent in the concepts of the Maori media as a development media. However, it means that Maori will not write a "good story" if it will harm their community. Their community is Te Ao Maori - the Maori World — not the mainstream media's community that is largely white and middle class. Against this the media has spent 100 years constructing Maori as a "them" — outside the mainstream community. Maori are a "them" conflicting with the mainstream 54 PACIFIC JOURNALISM REVIEW 82002 
white middle class "us".

This has serious consequences for news production by Maori reporters. Maori are alienated and colonised. Maori reporters see the world from the perspective of an alienated and colonised person. This means they will view the "instant history" they are asked to write about from that perspective, very different from a Pakeha reporter's perspective.

By asking them to write as a Pakeha reporter would is another step in the colonising process. It is asking them to assume the coloniser's perspective to become assimilated, to sublimate their culture and perspectives in the face of the dominant culture.

The media has long be criticised as an agent on colonisation, but clearly the journalism schools, which hope to train Maori in mainstream news media techniques are colonisers (albeit of a smaller population and on a more individual basis) because they attempt to fit Maori into the dominant cultural models, systems and forms, especially the forms of communication.

Recently on National Radio's Media Watch commentary programme the chief reporter of the Otago Daily Times criticised the journalism schools for turning out graduates who all looked the same ${ }^{10}$. Journalism Training Organisation CEO Bill Southworth applauded this as a sign that the schools were turning out a "quality product". However, the unasked question is: are the schools taking in people who all look the same, or are they taking different people and making them all the same. Either answer has consequences for potential Maori reporters.

If the former is the case, then there are very few Maori who look like Pakeha journalism school entrants. This could be why the schools and the news media are not successful in attracting the numbers of Maori they want to enter the profession. If the answer is the latter, then the schools are definitely colonisers. They will take Maori entrants and turn them into Pakeha journalists with brown skins.

This brings into question the fundamental reasons why the news media wants more Maori reporters.

If the news executives believe Maori reporters will get better Maori stories than Pakeha reporters, or that Maori will be more welcome in a Maori environment, then they are guilty of wanting to "brown wash" the news. "Brown wash" means putting brown faces in front of a Pakeha process in an effort to make it more acceptable to Maori. 


\section{INDEX}

\section{Conclusion}

To become truly bicultural the New Zealand news media will have to make significant changes, taking into account the issues raised in this paper. Journalism schools too, need to change because there will be major changes in New Zealand's population during the working life of their graduates. The news executives of the future, who will need to be truly bicultural, are the students graduating from the journalism schools now.

The schools need to be producing truly bicultural journalists, both Maori and Pakeha, who can report comfortably from both cultures. This means making Pakeha reporters aware of Maori processes and perspectives, of teaching them about Maori culture, while teaching Maori reporters able to use western communications processes and teaching them Pakeha culture. Each approach must happen in a way which allows the students to maintain their own identity. And both involve different approaches to teaching .

In the end, I am arguing that eductors need to be aware of these issues and to take them into account when faced with Maori and Pakeha students. The kinds of changes to the news styles and presentations I am arguing for will not happen overnight. However, there is a growing Polynesian population in New Zealand and a growing Maori population within that. If Maori turn away from the mainstream news media and to their own news, the mainstream media will become the minority media, within the lifetime of current graduates.

Educators and academics are the change agents for the future, while working journalists can be the agents of change within the communities, as long as they truly understand the societies And cultures they live with, and report on.

\section{Notes:}

${ }^{1}$ Stuart (1996)

${ }^{2}$ Hawke's Bay Today, 4 October 2001, p13; October 10, p12

${ }^{3}$ The Dominion, 27 September 2001, p2.

${ }^{4}$ Tucker, (1992), p89

${ }^{5}$ Tucker, (1992) pxiii

${ }^{6}$ Todorov (1971) p111

${ }^{7}$ For a more detailed account see Stuart, (2000)

${ }^{8}$ Robie, (1994) part 4. See also Robie, (1995).

${ }^{9}$ For a full discussion, see Stuart (1998).

${ }^{10}$ Mediawatch, New Zealand National Radio, Sunday, 28 October 2001, 9 am to $9.30 \mathrm{am}$. 


\section{BICULTURALISM}

\section{Bibliography:}

Books:

Altschull, Herbert J, (1995). Agents of Power: the media and public policy, 2nd ed. Longman, USA.

Blythe, M (1994). The Naming of the Other, images of the Maori in New Zealand film and television. Metuchen, NJ: The Scarecrow Press.

Comrie, Margie and McGregor, Judy (eds) (1992). Whose News? Palmerston North: Dunmore Press.

Curran, James, Gurevitvch, (eds) (1991). Mass Media and Society. Edward Arnold.

Dahlgren P \& Sparks, C (eds) (1993). Communications and Citizenship. London: Routledge.

Fiske, J (1987). Television Culture. London: Routledge.

Habermas, J (1989). The Structural Transformation of the Public Sphere, (Burger, T. trans.). Cambridge, Mass: MIT Press.

Robie, David (1994). Pacific Mass Communications Handbook. Port Moresby, PNG: University of Papua New Guinea.

Robie, David (1995). Nius Bilong Pasifik: Mass Media in the Pacific. Port Moresby, PNG: University of Papua New Guinea Press.

Spoonley, P. \& Hirsh, W. (eds) (1990). Between the Lines: Racism and the New Zealand media. Auckland: Heinemann Reid.

Todorov, T (1977). The Poetics of Prose. New York: Cornell University Press.

Tucker, J (1992). Kiwi Journalist: A Practical Guide. Auckland: Longman Paul.

Journals and articles:

Fox, D (1998). "Time to Step Aside", in Mana, No 21, April/May, pp21-26.

Robie, David (ed). Pacific Journalism Review, Port Moresby, PNG: University of Papua New Guinea Press, Vol 1, no 1 and Vol 2, no 2.

Stuart, I (1995). "Journalism Training and the Free Press", in New Zealand Journal of Media Studies, Massey University, Vol 2, Number 1 pp 83-88

Stuart, I (1996). "Maori and Tauiwi Media", in Pacific Journalism Review, November, Vol 3 No 2, pp 102-112.

Stuart, I (2000). "The Contemporary Maori Media: Developing a Developmental Media”, in He Tuhinga Aronui: The Journal of Maori Writings. Auckland: Auckland University of Technology, Vol 4, Number 1, May 2000, pp1 - 13.

Interviews:

Harmer, John, foundation member, Te Toa Takitini Radio; Te Reo Iririangi o Ngati Kahungunu, numerous discussions, 1994-1999.

Joseph, Pare, station manager, Te Reo Irirangi o Maniapoto, 10 December 1996.

Pouwhare, Robert, director, Aotearoa Television Network, 26 April 1996.

Rangi, Kevin, general manager, Aotearoa Maori Radio, 26 April 1996.

Sarich, Sue, editor, Kia Hiwa Ra, 10 December 1996. 


\section{INDEX}

Teepa, Potiki, journalist, Te Reo Irirangi o Kahungunu, 27 September 1996.

Te Rito, J. chairperson, Te Reo o Ngati Kahungunu Inc (Radio Kahungunu), ongoing discussions 1993-1998.

Tumahai, Andrew, editor-in-chief, Te Maori News, 26 April 1996.

Wilson, Gary, associate editor, Mana, 26 April 1996.

Wright, Joel, lecturer, Aboriginal Media Studies, Charles Sturt University, 14 July 1996.

$\square$ Ian Stuart is lecturer in Maori Studies at the Eastern Institute of Technology in Napier, New Zealand, and is also a journalism educator. He is a member of the editorial board of Pacific Journalism Review.

istuart@eit.ac.nz

bo you want to work in the medray investigate

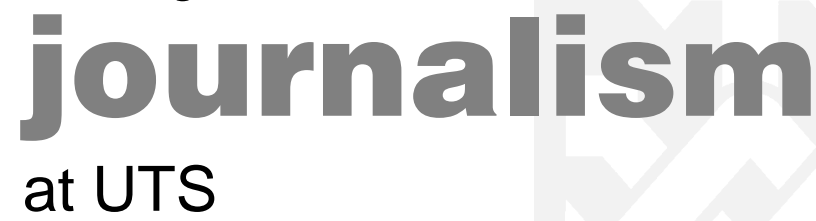

\section{Leading Australia in postgraduate journalism education}

On offer in 2002

- Master of Arts in Journalism

- Graduate Diploma in Communication (Journalism)

- Graduate Certificate in Journalism

With streams in print, radio, television and internet journalism including

- Industry placements 